УДК $340.1 ; 342.7$

DOI https:// doi.org/10.32837/yuv.v0i2.1714

В. Стрільчук,

кандидат юридичних наук, доцент кафедри правознавства

Поліського національного університету

\title{
ОСОБЛИВОСТІ РЕАЛІЗАЦІЇ ПРАВА \\ НА УЧАСТЬ У МІСЦЕВОМУ САМОВРЯДУВАННІ: АНАЛІЗ КРІЗЬ ПРИЗМУ ЗАБЕЗПЕЧЕННЯ ПРИНЦИПУ РІВНОСТI ЧОЛОВІКА ТА ЖІНКИ
}

\begin{abstract}
Проблематика забезпечення прав людини практично завжди була, залишається сьогодні й буде в центрі уваги представників різних напрямів соціогуманітарної наукової думки. Права людини досліджуються крізь призму різносторонніх аспектів та з урахуванням різноманітних факторів: правових, політичних, філософсько-гуманістичних, соціально-економічних, екологічних, духовно-ідеологічних.
\end{abstract}

Актуальність дослідження прав людини в умовах глобалізації підтверджується надзвичайною важливістю цього питання як для окремого індивіда мікро-, мезо- й макросоціуму, держави та світу загалом, що закономірно виражається через значну кількість наукових заходів, які присвячені цим питанням, значну чисельність різних наукових робіт, у яких розглядаються різносторонні аспекти названого явища $[1$, с. 121].

Так, у питаннях дослідження прав людини в умовах глобалізації наукову основу становлять праці таких учених, як I.I. Балаклицького, Є.В. Білозьорова, Л.О. Васечко, Ю.О. Волошина, B.Н. Денисова, О.Р. Дашковської, Д.С. Комарницького, M.I. Козюбри, О.Л. Копиленка, А.Р. Крусян, А.В. Кузьміних, Л.С. Леонової, Є.О. Львової, M.M. Мацькевича, Ю.М. Оборотова, Н.M. Оніщенко, М.M. Ониськіва, П.М. Рабіновича, О.I. Руднєвої, О.Ф. Скакун, В.М. Співака, Л.Г. Удовики, М.Г. Хаустової, Г.І. Чернишевої,
Т.П. Чубко, В.М. Шаповала, Ю.С. Шемшученка, та багатьох інших.

Чимало аспектів розвитку безпосередньо муніципальних прав і свобод людини в умовах глобалізації досліджували такі вчені-правознавці, як М.О. Баймуратов, Ю.Ю. Бальцій, О.В. Батанов, I.В. Дробуш, Б.Я. Кофман, П.М. Любченко. Водночас одним із пріоритетних питань було й залишається сьогодні забезпечення принципу рівності чоловіка та жінки під час реалізації права на участь у місцевому самоврядуванні.

Метою дослідження $є$ розкриття окремих аспектів реалізаціі права на участь у місцевому самоврядуванні, зокрема крізь призму забезпечення принципу рівності чоловіка та жінки.

Дійсно, права людини - це не застигла «ідеологія», а область етичної та правової думки, яка розвивається [2]. Вони не статичний, раз і назавжди даний інститут. Права людини постійно збагачуються [3, с. 51]. Як слушно зауважує академік Ю.С. Шемшученко, права людини, - історично мінлива категорія, яка еволюціонує разом із суспільством та державою [4, с. 8].

Необхідно зазначити, що саме права людини $€$ ключовою ланкою глобалізації. Із їх допомогою стає можливим побороти відчуження між людиною, суспільством та державою [5, с. 111]. Водночас безпосередньо на місцеве самоврядування покладається одна 3 найважливіших ролей у реалізаціï окресленого вище архіважливого 
завдання сучасності - поєднати в єдине ціле інтереси держави, суспільства та особи. Адже головний сенс та сутність місцевого самоврядування полягають у тому, щоб на рівні кожної окремо взятої особи здійснювати гармонізацію прав та свобод людини і громадянина 3 інтересами держави та суспільства. Саме така спрямованість місцевого самоврядування відповідає ідеям сучасної демократичної правової соціальної держави, вищою цінністю якої є людина, їі права та свободи [6, с. 15]. Така спрямованість місцевого самоврядування не тільки відповідає вимогам сучасного глобалізованого світу, але й дає реальний шанс безпосередньо втілити в життя позитивні тенденції глобалізації, а також уникнути їі негативних явищ та загроз, надто в умовах сьогодення, коли майже ввесь світ переживає негативні наслідки пандеміі COVID-19, яка ще більше загострює економічну та соціальну нерівність, соціальне відчуження та інші негативні явища та процеси.

Доволі рельєфно ілюструє проблему реалізації права на участь у місцевому самоврядуванні в умовах глобалізації екстраполяція на локальний рівень загальновизнаного в сучасному світі принципу рівності чоловіка та жінки [7, с. 86]. На жаль, у сучасному суспільстві є проблема, пов'язана 3 дискримінацією за ознакою статті. До того ж вона має глобальний характер. Безсумнівно, окреслена проблема $€$ актуальною, тому й забезпечення рівності за ознакою статті, розширення прав та можливостей усіх жінок (Ціль № 5), скорочення нерівності всередині країн (Ціль № 10) є глобальними цілями стійкого розвитку, які світова спільнота зобов'язується досягти до 2030 року.

Відповідно до даних Global Gender Gap Index 2018 Україна посіла лише 65 місце зі 149 країн у світовому рейтингу рівності за ознакою статі. Так, в Україні критично мало жінок на посадах, які потребують прийняття політичних рішень. Фактично, національний показник $(0,107)$ у $6-5$ разів менший від країн лідерів - Ісландії $(0,674)$, Норвегії $(0,563)$ та Швеції $(0,512)$ [8].

На муніципальному рівні, тобто рівні функціонування місцевого самоврядування, відповідна проблема також стоїь достатньо гостро. Підтвердженням тому слугують різні статистичні дані. Зокрема, для прикладу, Комітет виборців України проаналізував результати виборів до міських рад м. Києва та міст-обласних центрів. За даними із 22 міських рад, обрано 214 депутаток та 969 депутатів. Таким чином, середній рівень представництва жінок у міських радах - 18,1\%. Із 214 депутаток, обраних за результатами виборів, 13 (або 6,1\%) були лідерами партійних списків. Для порівняння, серед 5552 жінок-кандидаток у міські ради було 58 лідерів списків, тобто $1 \%$. Із одного боку це свідчить про те, що закріплення за жінками місць у прохідній частині списку сприяє проходженню в місцеві ради. 3 іншого боку - 93,9\% обраних жінок-депутаток отримали мандат завдяки підтримці виборців, а не закріпленому місцю у списку [9].

Тобто в суспільстві є потенціал для підтримки жінок на обрані посади, навіть за умови порівняно меншого за чоловіків-кандидатів ресурсного забезпечення агітації. Загалом, зазначають експерти, порівняно зі складом міських рад попереднього скликання, ситуація з гендерним балансом покращилась в 11 із 22 радах. Поріг у $30 \%$ було подолано тільки в одній міській раді - а саме в Чернігівській. Водночас робиться висновок, що низький рівень представництва жінок у місцевих органах влади, котрі обираються, не пов'язаний із небажанням жінок іти в політику [10, с. 7].

За результатами місцевих виборів 2015 року в обласних радах переважно додалось по 1-2 «жіночих» мандати (14 областей). Вінницька, Черкаська та Одеська облради втратили 10, 9 та 7 мандатів депутаток-жінок відповідно. $Є$ різке зростання у Львові та Хмельницькому - 9 та 8 відповідно. 
Але тому, що попередній склад цих рад був занадто «чоловічим», впливу квот експерти не побачили. У більшості областей їх ураховувала одна 3 партій або не враховувала жодна. Якщо оцінювати суспільно-політичні можливості жінок загалом, то вони лишаються нерівними із чоловіками. Їх частка у виборчих органах та на призначуваних посадах високого рівня все ще залишається критично низькою [11, с. 17-18].

Серед 214 депутатів міських рад і 252 депутатів обласних рад, обраних за результатами виборів у 2015 році, жінки як лідери партійних списків становили лише $6,1 \%$ і 5,9\% відповідно [12].

$\mathrm{y}$ зазначеному вище аспекті доволі цікавим $€$ відповідний зарубіжний досвід. Так, згідно з даними організації «Об'єднані міста й місцеві уряди» (UCLG), у світі лише 5\% жінок-мерів та 20\% жінок-депутатів. Лише 10 зі 195 світових столиць очолюють жінки, що становить $5,1 \%$. Дещо вищим $€$ рівень представництва жінок-мерів у містах-мільйонниках - 29 жінок із 493 мерів міст, що становить 6,1\%. За даними Спілки асоціацій місцевих органів влади південно-східної Європи (NALAS), яка охоплює 14 повних членів національних асоціацій $\mathrm{MCB}, 7$ асоційованих членів, 9000 - органів місцевої влади, які представляють 80 млн мешканців, лише 8,4\% міських голів у південно-східній Європі - це жінки, 91,6\% - чоловіки; 29,9\% депутатів у південно-східній Європі - це жінки, 70,1\% - це чоловіки [13].

Таким чином, питання реалізації принципу рівності за ознакою статті в територіальних громадах та діяльності органів місцевого самоврядування відносяться до найбільш актуальних у теоретичному та прикладному значенні, вирішення яких $€$ своєрідним детектором демократичності та цивілізованості суспільства [14, с. 6]. Водночас за справедливим зауваженням О.В. Батанова, серед ключових викликів та можливостей у питаннях рівності за ознакою статі на місцевому рівні в Україні є: сприяння впровадженню врахування ознаки статі в діяльність органів місцевого самоврядування та посиленню ролі територіальних громад у цьому напрямі, впровадження відповідної перспективи в політиці на місцевому рівні для забезпечення доступу до державної та муніципальної політики для всіх громадян, що має впливати та повсякденне життя жінок і чоловіків, подолання пов'язаних із цим стереотипів у територіальних громадах та сприяння рівності за ознакою статі в локально-регіональному вимірі функціонування соціуму, розробка та реалізація стратегій рівності за ознакою статі та впровадження відповідного підходу в різноманітних аспектах життя територіальних громад та діяльності органів місцевого самоврядування тощо.

Водночас, як зазначається в положеннях Всесвітньої декларації Міжнародного союзу місцевих органів влади про роль жінки в місцевому самоврядуванні, система місцевого управління займає унікальне положення 3 погляду сприяння боротьбі за статеву рівність на глобальному рівні та може справити серйозний вплив на положення жінок та ситуацію в галузі рівності за ознакою статті в усьому світі; саме така система являє собою рівень керівництва, найбільш близький до громадян, діючи як працедавець та надаючи послуги (ч. 10). Також у частині 12 указаного документу зазначається й мотив його розробки: «<..> утворення стійких, заснованих на принципах рівноправ'я та демократії місцевих органів управління, де б жінки й чоловіки мали рівний доступ до процесу прийняття рішень, рівний доступ до послуг i рівний статус у процесі надання цих послуг, гендерна проблематика має бути долученою до всіх сфер директивної й управлінської діяльності місцевих органів управління (ч. 12).

$\mathrm{He}$ менш важливою у створенні належних нормативних умов для реалізаціі права на участь у місцевому самоврядуванні 3 урахуванням принципу рівності чоловіка та жінки $€$ Європейська хартія рівності жінок 
і чоловіків на місцевому рівні, розроблена у 2006 році Радою європейських муніципалітетів і регіонів (CEMR) [15]. Європейська хартія як інструмент політичної волі дуже корисна для органів місцевого самоврядування. Підписана міськими головами, ця Хартія надає чіткі рекомендації органам місцевого самоврядування щодо заходів у межах ї компетенцій, які потрібно впроваджувати для забезпечення рівноправ'я між чоловіками та жінками (а також національними меншинами, недієздатними особами, ВПО тощо) [16].

Наведемо й інші приклади. Важливим документом міжнародно-правового характеру, який сприяє подоланню дискримінації за ознакою статті під час реалізації права на участь у місцевому самоврядуванні є Декларація про міста та інші населені пункти в новому тисячолітті, країни-учасниці якої вважають за необхідне за допомогою відповідних механізмів забезпечити, щоб жінки відігравали ефективну роль у прийнятті рішень місцевими органами влади, заявили про свою цілеспрямованість щодо забезпечення рівності за ознакою статі в розвитку населених пунктів та сповнені рішучості підтримувати рівність за ознакою статі та розширення можливостей жінок як ефективних способів боротьби з бідністю та стимулювання розвитку населених пунктів, які будуть по-справжньому стійкими. «Ми далі беремо на себе зобов'язання формулювати та зміцнювати політику та практику забезпечення повної та рівноправної участі жінок у плануванні населених пунктів та прийнятті рішень», - зазначається в Декларації [17].

Варто зазначити, що, окрім Конституції України (стаття 24), також на національному рівні нормативно-правову основу в регулюванні питання щодо забезпечення рівних можливостей чоловікам та жінкам, зокрема під час реалізації права на участь у місцевому самоврядуванні, відіграють окремі положення Закону України «Про забезпечення рівних прав та можливостей жінок і чоловіків» від 8 вересня
2005 року № 2866-IV (з відповідними змінами та доповненнями) [18]. Головною метою його прийняття $€$ досягнення паритетного становища жінок і чоловіків у всіх сферах життєдіяльності суспільства шляхом правового забезпечення рівних прав та можливостей жінок і чоловіків, ліквідації дискримінації за ознакою статі та застосування спеціальних тимчасових заходів, спрямованих на усунення дисбалансу між можливостями жінок і чоловіків реалізовувати рівні права, надані їм Конституцією й законами України.

Відповідно до статті 7 вищезгаданого Закону, поряд із органами державної влади, підприємствами, установами та організаціями, громадськими об'єднаннями, також й органи місцевого самоврядування сприяють збалансованому представництву статей в управлінні та прийнятті рішень. Задля забезпечення рівних прав та можливостей жінок і чоловіків у своїй діяльності всі вищеперелічені суб'єкти можуть застосовувати позитивні діі, тобто спеціальні тимчасові заходи, котрі мають правомірну об'єктивно обгрунтовану мету, спрямовану на усунення юридичної чи фактичної нерівності в можливостях жінок і чоловіків щодо реалізації прав і свобод, установлених Конституцією й законами України (стаття 1 Закону).

Згідно із ч. 2, 4 статті 12 вищевказаного Закону в органах місцевого самоврядування визначається вповноважена особа (координатор) із питань забезпечення рівних прав та можливостей жінок і чоловіків, запобігання та протидії насильству за ознакою статі. Також органи місцевого самоврядування можуть утворювати консультативно-дорадчі органи, призначати радників із питань забезпечення рівних прав та можливостей жінок і чоловіків, запобігання та протидії насильству за ознакою статі.

Забезпечення рівних прав та можливостей жінок і чоловіків у сфері служби в органах місцевого самоврядування полягає в такому (стаття 16 Закону): призначення на службу в органи місце- 
вого самоврядування повинно здійснюватись із дотриманням представництва кандидатур кожної статі; дискримінація за ознакою статі під час прийняття на службу в органи місцевого самоврядування й у процесі ї̈ проходження забороняється; керівники органів місцевого самоврядування зобов'язані забезпечити рівний доступ громадян до служби в органах місцевого самоврядування відповідно до кваліфікації і професійної підготовки, незалежно від статі претендента; формування кадрового резерву для заміщення посад в органах місцевого самоврядування, просування їх за кар'єрними сходинками здійснюється із забезпеченням рівних прав та можливостей для жінок і чоловіків.

Відповідно до Державної соціальної програми забезпечення рівних прав та можливостей жінок і чоловіків на період до 2021 року, затвердженої Постановою Кабінету Міністрів України від 11 квітня 2018 р. № 273, пї ключова мета полягає в удосконаленні механізму забезпечення рівних прав та можливостей жінок і чоловіків у всіх сферах життя суспільства та впровадження європейських стандартів рівності. Водночас серед шляхів та способів розв'язання проблеми недостатнього рівня впровадження принципу забезпечення рівних прав та можливостей жінок і чоловіків, зокрема під час реалізації права на участь у місцевому самоврядуванні, передбачається розв'язати шляхом застосування комплексного підходу та здійснення заходів, спрямованих на виконання таких пріоритетів, як: удосконалення нормативно-правової бази, впровадження статистичних показників у сфері забезпечення рівних прав та можливостей жінок і чоловіків; підвищення професійного рівня посадових осіб місцевого самоврядування щодо забезпечення рівних прав та можливостей жінок і чоловіків; виконання договірних та інших міжнародних зобов'язань щодо забезпечення рівних прав та можливостей жінок і чоловіків, зокрема через збільшення частки жінок серед депутатів обласних та місцевих рад (міст обласного значення).

Очікуваними результатами виконання Державної соціальної програми забезпечення рівних прав та можливостей жінок і чоловіків на період до 2021 року, власне, в питанні збільшення частки жінок серед депутатів обласних, районних i міських рад (починаючи з 2019 року), повинна бути частка, не менша, ніж 25\% жінок від загального складу депутатів відповідних рад.

Серед важливих кроків, спрямованих на реальне досягнення таких показників, є вивчення та застосування відповідного позитивно апробованого досвіду провідних зарубіжних країн, його врахування безпосередньо в практиці муніципально-правового регулювання відносин, пов'язаних із забезпеченням рівних можливостей людині брати участь у місцевому самоврядуванні, незалежно від ознаки статті, усунути в цьому питанні будь-які обмеження чи привілеї за ознакою статі.

Після виборів в Італії, котрі проходили в червні, кожен третій депутат місцевих рад - це жінка. Також станом на 31 грудня 2017 року $33 \%$ адміністративних посад обіймають жінки. Національна асоціація муніципалітетів Італії (ANCI) розробила національний стратегічний план на період 2017-2020 років про насилля чоловіків над жінками.

Надзвичайно важливим $є$ досвід у цій сфері Спілки асоціацій місцевих органів влади Південно-Східної Європи (NALAS). Ця Спілка є мережею асоціацій, які разом становлять 9000 органів місцевої влади у країнах південно-східної Європи. Метою є покращення децентралізаціі та ролі органів місцевого самоврядування та підсилення державних органів влади. У 2016-2017 роках близько $29.9 \%$ депутатів рад у південно-східній Європі були жінки. Жінки становлять $20 \%$ у Генеральній Асамблеї Спілки та $61 \%$ працівників. Спілка сприяє впровадженню Європейської Хартії рівності жінок та чоловіків на місцевому рівні. У цьому контексті у 2016 році Генеральна Асамблея при- 
йняла напрям політики, спрямований на сприяння гендерній рівності на місцевому рівні. Також на операційному рівні Спілка пропонує онлайн-курс «Вступ до поняття гендерного підходу на місцевому рівні» та розробила методологію підсилення гендерної перспективи в наданні послуг на місцевому рівні. Спілка регулярно відзначає нагородою "GENiYOUTH Municipal Initiatives Award” відповідні муніципалітети, які впроваджують ініціативи із залучення молоді та жінок до своїх громад.

Також у вищезазначеному контексті вартий уваги підготовлений до обговорення в лютому 2018 року документ «Гендерна рівність у місцевому політичному житті та гендерна концепція в місцевій політиці в Україні», підготовлений у межах проєкту «Сприяння розвитку місцевої демократії в Україні», який упроваджується Конгресом місцевих та регіональних влад Ради Європи відповідно до Плану дій Ради Європи для України на 2015-2017 рр. Проєкт спрямований на покращення впровадження принципів демократії в Україні шляхом удосконалення інституційних та лідерських здібностей обраних представників місцевого рівня та поширення на загальнонаціональному рівні кращої практики місцевої демократії.

Зокрема, в його III Частині «Інструменти та рекомендації для органів місцевої влади» сформовано низку рекомендацій органам місцевого самоврядування щодо недопущення на рівні функціонування місцевого самоврядування дискримінації за статевою ознакою, зокрема під час реалізації права на участь у місцевому самоврядуванні як чоловіками, так і жінками. Убачаємо за доцільне зазначити деякі з них.

Так, органи місцевого самоврядування можуть прийняти місцеву декларацію щодо рівності за ознакою статі, за якою вимагається представництво принаймні 40\% жінок. Доцільно також запровадити систему наставництва як програму розвитку спроможностей для жінок-політиків. Мережа депутатів місцевих рад здатна стати благодатною базою для обміну ідеями й гарними практиками, розвитку спроможностей і розширення прав та можливостей жінок-політиків. 3 огляду на це співпрацю між мережами депутатів місцевих рад та міжфракційним об’єднанням Верховної Ради «Рівні можливості» можна посилити, така співпраця стане важливою для координування діяльності й кампаній підтримки на різних рівнях. Необхідно впроваджувати й підтримувати на місцевому рівні такі практики як консультації із чоловіками та жінками про місцеві пріоритети. Під час цього процесу варто організовувати окремі зустрічі із жінками для обговорення пріоритетів та можливостей, які можна застосувати в місцевій політиці. Жіночі організації як постачальники соціальних послуг мають фінансуватись із місцевих бюджетів. Окрім того, потрібно сприяти активізму жінок у місцевих сільських громадах, щоб сприяти довготривалому розширенню прав і можливостей жінок у процесі прийняття рішень [16]. Цінність таких рекомендацій $€$ очевидною, іï зміст повинен лягати в основу перспективного законодавства, а також відповідної муніципальної нормотворчості.

На допомогу органам місцевого самоврядування в забезпеченні принципу рівності чоловіка та жінки у громадах покликані міжнародно-правові стандарти локальної демократії. Серед них передусім виокремимо Європейську хартію рівності жінок і чоловіків у житті місцевих громад 2004 року. Бувши розробленою Радою європейських муніципалітетів і регіонів (РЄMP), Хартія закликає місцеві та регіональні органи самоврядування взяти на себе зобов'язання використовувати наявні повноваження й партнерства для досягнення більшої рівності своїх громадян. Фундаментальними принципами діяльності підписанти Європейської хартії рівності жінок і чоловіків у житті місцевих громад визнають:

1) рівність жінок і чоловіків $є$ фундаментальним правом;

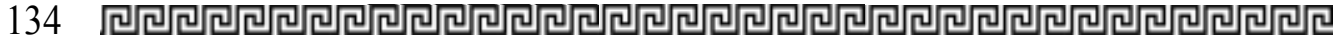


2) для забезпечення рівності жінок і чоловіків необхідно боротись проти різноманітних форм дискримінації та зневаги;

3) збалансована участь жінок і чоловіків у прийнятті рішень є передумовою демократичного суспільства;

4) викорінення стереотипів є основоположним для досягнення рівності між жінками й чоловіками;

5) для досягнення рівності жінок і чоловіків необхідно інтегрувати гендерну перспективу до всіх видів діяльності місцевих і регіональних органів самоврядування;

6) плани дій і програми з належним фінансуванням $€$ необхідними інструментами для сприяння досягненню рівності жінок і чоловіків.

Варто зазначити, що підписання вказаної Хартії дозволяє органам місцевого самоврядування публічно продемонструвати відданість принципам рівності жінок і чоловіків та зобов'язання реалізовувати їх на території своєї діяльності. Для цього кожний орган-підписант розробляє План дій для досягнення рівності, в якому визначено пріоритети, діï та ресурси для ї реалізаціі. Станом на сьогодні Європейську хартію рівності жінок і чоловіків у житті місцевих громад прийняли практично всі міста Європи. В Україні цей рух лише починається, відповідне рішення схвалили лише Вінниця (2017 рік), Житомир та Ірпінь Київської області (2018 рік) [19].

Отже, підсумовуючи все зазначене вище, можемо дійти висновку, що у сфері місцевого самоврядування є проблематика, пов'язана з недотриманням принципу рівності чоловіка та жінки, що, зі свого боку, негативно відображається на ефективності забезпечення права на участь у місцевому самоврядуванні. Аналіз як нормативних, так і прикладних аспектів прояву цієї проблематики дає підстави стверджувати про неналежну врегульованість вітчизняним муніципальним законодавством цього питання, зокрема відсутність дієвого механізму забезпечення принципу рівності чоловіка та жінки у сфері місцевого самоврядування, його невідповідність міжнародно-правовим (європейським) стандартам.

Однією 3 важливих умов дійсно ефективного забезпечення права на участь у місцевому самоврядуванні $€$ врахування принципу рівності чоловіка та жінки. Адже такий підхід засвідчуватиме реальне, а не декларативне слідування загальновизнаним інститутам демократії, прагнення українського суспільства та держави побудувати модель місцевого самоврядування на зразок провідних європейських країн, де як чоловіки, так і жінки матимуть абсолютно однакові можливості брати активну участь в управлінні місцевими справами, де як у діяльності органів місцевого самоврядування, так і в безпосередньому представництві інтересів територіальних громад буде прослідковуватись паритет за ознаками статі, подолання в соціумі пов'язаних із цим помилкових стереотипів.

У статті досліджено особливості, а також проблеми реалізаціі права на участь у місцевому самоврядуванні, безпосередньо пов'язані із забезпеченням принцииу рівності чоловіка та жінки в Україні. Адже в сучасному суспільстві очевидною є проблема, пов' язана з дискримінацією за ознакою статті. Власне, вона має не тільки локальний, але і глобальний характер, що ще більше актуалізує необхідність відповідного дослідження.

Забезпечення рівності за ознакою статті, розширення прав та можливостей усіх жінок (Ціль № 5), скорочення нерівності всередині країн (Ціль № 10) є Глобальними цілями стійкого (збалансованого) розвитку, які світова спільнота зобов'язується досягти до 2030 року.

Аналіз як нормативних, так $i$ прикладних аспектів прояву цієї проблематики дає підстави стверджувати про неналежну врегульованість вітчизняним муніципальним законодавством цього питання, зокрема відсутність дієвого механізму забез- 
печення принципу рівності чоловіка та жінки у сфері місиевого самоврядування, подекуди його невідповідність міжнародно-правовим (європейським) стандартам.

Серед важливих кроків, спрямованих на реальне досягнення зазначених изілей на національному, а також вітчизняному муніципальному рівнях $\epsilon$ необхідність у вивченні та застосуванні відповідного позитивно апробованого досвіду провідних зарубінних країн, його врахування безпосередньо в українській практиці муніципально-правового регулювання відносин, пов'язаних із забезпеченням рівних можливостей людини брати участь у місцевому самоврядуванні, незалежно від ознаки статі, усунути в цььому питанні будь-які обмеження чи привілеї за вказаною ознакою. Такий підхід засвідчуватиме реальне, а не декларативне слідування загальновизнаним інститутам демократіі, прагнення українського суспільства та держави побудувати модель місиевого самоврядування на зразок провідних європейських країн, де як чоловіки, так $і$ жінки матимуть абсолютно однакові можливості брати активну участь в управлінні місцеевими справами, де як у діяльності органів місцевого самоврядування, так $i$ в безпосередньому представництві інтересів територіальних громад буде прослідковуватись паритет за ознаками статі, подолання в соиіумі пов'язаних із изм помилкових cmepeomunis.

Ключові слова: глобалізація, права людини, муніципальні права і свободи, стійкий розвиток, міжнародні стандарти, принцип рівності.

Strilchuk V. Realization specifics of the right to participate in local self-government: analysis through the lens of the principle of gender equality provision

The article studies the specifics, as well as the problems of realization of the right to participation in local self-government, directly related to the provision of gender equality in Ukraine. The matter is that the problem of discrimination on the grounds of gender is evident in modern society. It has not only local, but also global characteristics; and this emphasizes once more the need in relevant research.

The provision of equality on the grounds of gender, the expansion of rights and possibilities of all women (Aim 5), inequality reduction inside states (Aim 10) are Global aims of stable (balanced) development, which the global society is committed to have achieved by 2030.

The analysis of both regulatory and action-oriented aspects of this problematics' demonstration gives grounds to state an inadequate regulation of this issue by national local government legislation, specifically the absence of active mechanism of the principle provision as to gender equality in the sphere of local self-government, at times its nonconformance with international legal (European) standards.

Among important steps, aimed at real achievement of the stated aims at the national, as well as at the local government levels, is the need to study and apply the positively approved experience of leading foreign states, its consideration in direct Ukrainian practice of municipal-legal regulation of relationships related to the provision of a person's equal possibilities to participate in local self-government, irrespective of a person's gender, to eliminate any gender-related restrictions or privileges in this issue. Such approach will testify to real, but not declarative observance of universally received democratic institutes, to the strivings of Ukrainian society and state for building a local self-government model by the example of leading European states, where both men and women shall have absolutely equal possibilities of participating actively in local matters management. And in this model, both of local self-government bodies and via direct representation of 
territorial communities' interests, the gender parity will be observed and the corresponding erroneous stereotypes will be overcome.

Key words: globalization, human rights, municipal rights and freedoms, stable development, international standards, equality principle.

\section{Література}

1. Васечко Л.О. Еволюиія прав людини під впливом процесів глобалізації. Форум права. 2010. № 4. С. 121-126.

2. Компас : Посібник з освіти в області прав людини за участі молоді. URL: http: / / www.coe.int/uk/web/compass / theevolution-of-human-rights (дата звернення: 20.05.2020)

3. Загальна теорія права: підручник / за ред. М.I. Козюбри. Київ : Baime, 2015. 392 c.

4. Проблеми реалізації прав $і$ свобод людини та громадянина в Україні: монографія / за ред. Н.М. Онішенко, О.В. Зайчука. Київ : Юридична думка, 2007. 424 с.

5. Колотова Н.В. Право и права человека в условиях глобализации. Государство и право. 2006. № 2. С. 253.

6. Савватеев А.И. Местное самоуправление как институт развития гражданского общества : автореф. дис. ... канд. полит. наук : 23.00.02. Екатеринбург, 2005. 27 c.

7. Батанов О.В. Муніципальне право в умовах глобалізації. Часопис Київського університету права. 2013. № 3. С. 84-88.

8. The Global Gender Gap Report 2018. URL: http:// reports.weforum.org / global-gender-gap-report-2018/ results-andanalysis / (дата звернення: 22.05.2020).

9. Фінальний звіт за результатами тендерного моніторингу на місиевих виборах 2015 року в Україні. URL: http: / / www.cou.org.ua / nodes / view / type:news/slug:finalnyi-zvit-zarezultatamygendernogo-monitoryngu-2015 (дата звернення: 22.05.2020).

10. Становлення та розвиток місцевого самоврядування в Україні: матеріали Всеукр. заоч. наук.-практ. конф., м. Хмельницький, 7 груд. 2018 р. Хмельницький : Хмельнищький університет управління та права, 2018. 167 с.

11. Альтернативна доповіды по виконанню Україною Конвениіі про ліквідацію всіх форм дискримінації щодо жінок : VIII Періодична доповідь / за ред. М.М. Ско- рик. Київ : БО БТ Київський інститут тендерних досліджень, 2017. 60 c.

12. Права жінок та гендерна рівність в Українi. URL: https://helsinki.org.ua/ en / women-s-rights-and-gender-equality-inukrainel (дата звернення: 22.05.2020).

13. Семра Амет. Сприяння гендерній політиці в діяльності асоціацій та органів місцевої влади. Кращі практики Спілки асоиіацій місиевих органів влади південно-східної Eвропи (NALAS) URL: https:/ / www.auc.org.ua / sites / default / files / semra_ nalas_gender_mainstreaming_at_local_level_ upd_ukr.pdf (дата звернення: 24.05.2020).

14. Батанов О.В. Деякі концептуальні питання конституиійно-правового забезпечення приниипу гендерної рівності у місцевому самоврядуванні. Становлення та розвиток місцевого самоврядування в Україні : матеріали Всеукр. заоч. наук.-практ. конф., м. Хмельницький, 7 груд. 2018 р. Хмельницький, Хмельницький університет управління та права, 2018. С. 3-10.

15. Ehe European charter for equality of women and men in local life, the Council of European Municipalities and Regions, Innsbruck May 2006. URL: http:// wrew. ccre.org/docs/charte_egalite_en.pdf (dama звернення: 25.05.2020).

16. Гендерна рівність у місиевому політичному житті та гендерна кониепиія у місцевій політиці в Україні. Документ до обговорення підготовлений $n$. Вишнею Бачановіч (Višnja Baćanović), консультантом з гендерної рівності за координаціі Департаменту співробітництва та зовнішніх відносин Секретаріату Конгресу місиевих та регіональних влад Ради Європи. URL: https: / / rm.coe.int/16808a2a51 (dama звернення: 26.05.2020).

17. Декларация о городах и других населенных пунктах в новом тысячелетии. Принята резолющией S-25/2 специальной сессии Генеральной Ассамблеи от 9 июня 2001 года. URL: https: / / zakon.rada.gov.ua/ laws/show/995_849 (дата звернення: 24.05.2020).

18. Про забезпечення рівних прав та можливостей жінок $i$ чоловіків : Закон України від 8.09.2005 p. № 2866-IV. URL: https: //zakon.rada.gov.ua/laws / show/2866-15 (дата звернення: 24.05.2020).

19. Європейська хартія рівності жінок і чоловіків у житті місиевих громад. Рада Eвропейських муніиипалітетів та регіонів. URL: http://auc.org.ua/sites / default / files/hartiya_ukr.pdf (даma звернення: 24.05.2020). 